\title{
ANALYSIS OF FACTORS INFLUENCING BATHING CONDITIONS ON BEACHES IN NITERÓI, BRAZIL
}

\author{
EMILLY VIEIRA BRAGA COELHO PINTO, FERNANDO GUIMARÃES VICENTE, \\ FLAVIO SILVA DE SANTANA, ANNA CAROLINA D’AVILA, \\ RAQUEL LIMA OLIVEIRA \& PAULO VITOR RIBEIRO MARQUES DA SILVA \\ Estácio de Sá University, Brazil
}

\begin{abstract}
Nowadays, Niteroi is considered the city with the best conditions of basic sanitation in the State of Rio de Janeiro. Despite that, Niteroi constantly lives with its beaches being classified, regarding the conditions of bathing, as unfit for recreation of primary contact, even after the implantation of the submarine emissary of Icarai, which assesses the disposition of the sewage collected from eight districts of the city. Thus, the objective of this work is to analyze the evolution of bathing conditions of the beaches of Niteroi, close to the submarine emissary of Icarai, and to identify the main factors that influence these conditions. For that, the following was performed: (i) a qualitative study of Guanabara Bay conditions; (ii) the effects of the disposal of the sanitary effluents by the submarine emissary; (iii) a statistical analysis of the bulletins of the beaches studied; and (iv) a correlation between the rainfall index and the bathing conditions. Through the studies carried out, it was verified that the sanitary sewage arrangement carried out by the submarine emissary minimally impacts the bathing conditions of the nearby beaches. On the other hand, due to the streamflow of the Guanabara Bay, the pollution irregularly disposed of by other cities around the Bay is responsible for bringing to the shore of the Niteroi beaches contaminants that directly interfere with the beaches' bathing conditions. It is important to note that Guanabara Bay receives the drainage of 55 rivers, of which t50 are considered completely polluted by sewage. Another factor that impacts the bathing conditions of beaches is the pluviometric precipitation index of the locality that, because of the high levels of seasonal precipitation, surpass the capacity of collection and treatment of the sewage treatment stations, causing the overflow of this sewage to the ocean.
\end{abstract}

Keywords: bathing conditions, sewage, submarine emissary, sanitation.

\section{INTRODUCTION}

According to the National Sanitation Information System [1], in a survey published in 2017, $52.4 \%$ of the Brazilian population has access to sewage collection and, from this percentage, only $46 \%$ of sewage is treated [2].

Despite these disastrous data on basic sanitation, the city of Niteroi, in the state of Rio de Janeiro, has been gaining prominence, according to an award granted by the Brazilian Association of Sanitary and Environmental Engineering [3], which in 2018, after evaluation of almost 250 cities of Brazil, awarded Niteroi as the best city in Rio de Janeiro and one of the best in the country in actions related to the universalization of basic sanitation. However, even being considered one of the cities that has made the most progress towards the universalization of basic sanitation, Niteroi coexists with the beaches of its coast classified, mostly, as unsuitable for bathing.

The pollution that hits the beaches affects the quality of its waters and has a significant impact on local tourist activities and the quality of life of its residents. Thus, contaminated water needs to be treated as a vehicle of disease, harmful to marine fauna and flora, and harmful to the local economy [4].

In order to reduce the impact on beach bathing and water diseases, an assessment of the individual and set consequences of sewage discharges is required [5], [6]. 
Thus, the present work aims to analyze the evolution of the bathing conditions of the beaches of Niteroi, near to the submarine emissary of Icarai, as well as the occurrence of waterborne disease transmission, and to identify the factors that interfere with the bathing conditions of the beaches of Niteroi.

\section{WATER DISEASES}

In general, regions suffering from lack of treated water and sewage systems tend to have higher rates of infectious diseases, which are transmitted due to contamination of rivers, lakes, streams, and even the sea by human and animal waste. However, this contamination can also occur through untreated sewage discharges, carried out by clandestine connections to the rainwater network [7], [8].

Among the main water diseases are gastroenteritis, cholera, typhoid fever, and hepatitis A. The following figures show the number of deaths (Fig. 1), the number of hospitalizations (Fig. 2), and the expenses incurred with hospitalizations (Fig. 3) caused by water diseases in the city of Niteroi.

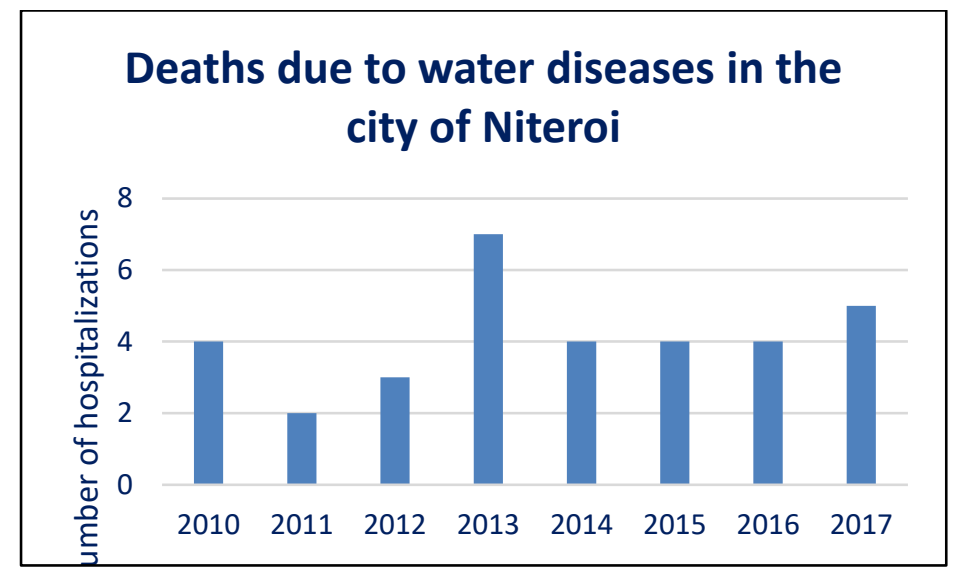

Figure 1: Deaths due to water diseases between 2010 and 2017 in Niteroi [9].

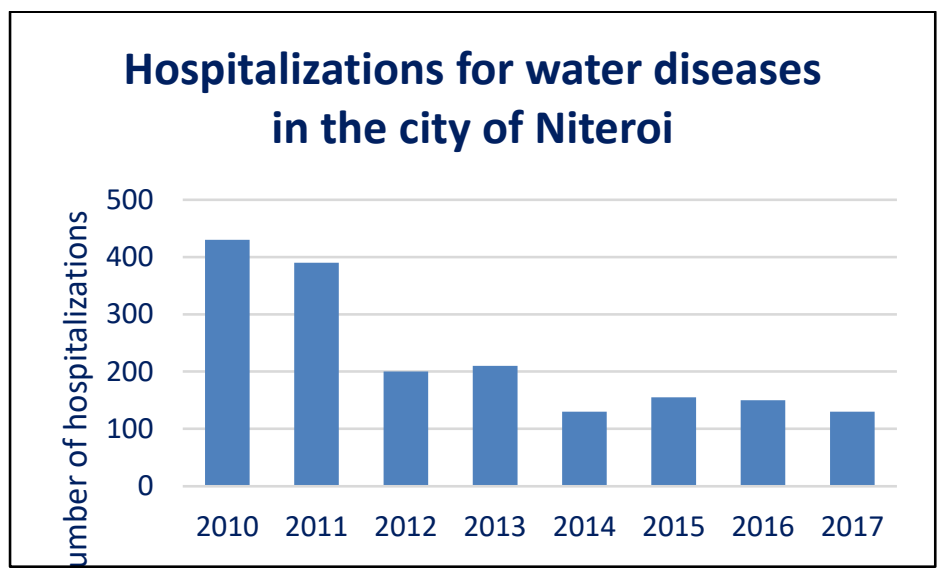

Figure 2: Hospitalizations for water diseases in Niteroi between 2010 and 2017 [9]. 


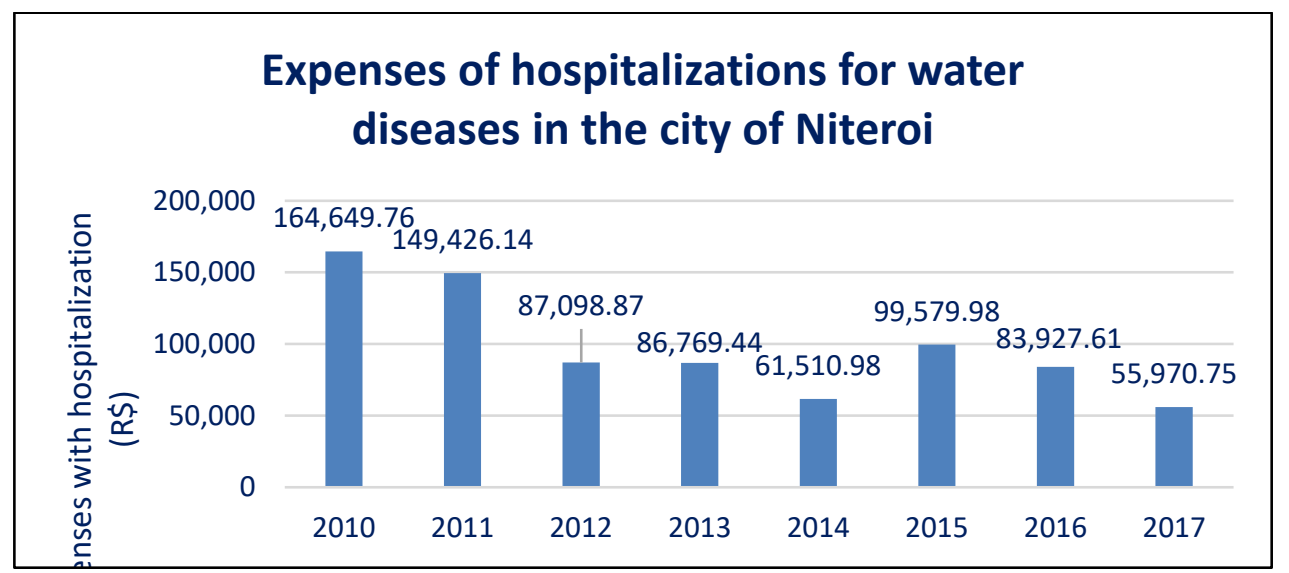

Figure 3: Expenses of hospitalizations for water diseases in Niteroi between 2010 and 2017 [9].

Table 1: Modelling scenarios.

\begin{tabular}{|l|l|}
\hline Scenarios & Considerations \\
\hline 1 & Clear sky summer \\
\hline 2 & Fully cloudy sky summer \\
\hline 3 & Clear sky winter \\
\hline
\end{tabular}

3 SUBMARINE EMISSARY

Knowing the movement of the effluent plume from a submarine emissary is extremely important because, from the concentrations of the contaminants present in it, it is possible to determine the areas that are most impacted by such releases [10]. According to Feitosa [11] and Ratti et al. [12], faecal coliform bacteria are considered a reference when it comes to contaminants. It is acceptable when values are below 1000 Fecal coliforms per $100 \mathrm{ml}$ [13].

Feitosa [11] modeled the evolution of the contaminant plume from the Icarai, Ipanema, and Barra da Tijuca submarine emissaries, considering three distinct scenarios (Table 1).

For all three scenarios, Feitosa [11] used a 14-day simulation period, regarding the radiation levels of January (summer) and June (winter). In the first and third scenarios, clear sky summer and clear sky winter, a maximum cloud cover of 5\% were considered, and in the second scenario, fully cloudy sky summer, $100 \%$ cloud cover was considered.

In all the scenarios mentioned, it is considered that water column density is homogeneous. Thus, during all simulations, the effluent plume will be superficial. In this sense, we can say that the solar radiation that acts on the plume occurs exclusively, according to the hourly and nebulous cover variations.

The results showed that the first scenario (Fig. 4), clear sky summer, was the one with the best bacterial decay condition. Due to the low presence of clouds, there was a higher incidence of solar radiation in the effluent plume and, consequently, higher and faster bacterial decay.

In the second scenario (Fig. 5), fully cloudy sky summer, there was low bacterial decay. This is due to the low amount of solar radiation reaching the plume, which makes the decay process slower and less effective. 
The third scenario (Fig. 6), clear sky winter, presented better results than the fully cloudy sky summer scenario, regarding bacterial decay, since clouds prevent the incidence of solar radiation, thus impairing the velocity of bacterial decay. When compared to the first scenario, clear sky summer, it presented lower decay speeds, which is to be expected, since, in summer, the incidence of solar radiation is higher than in winter.

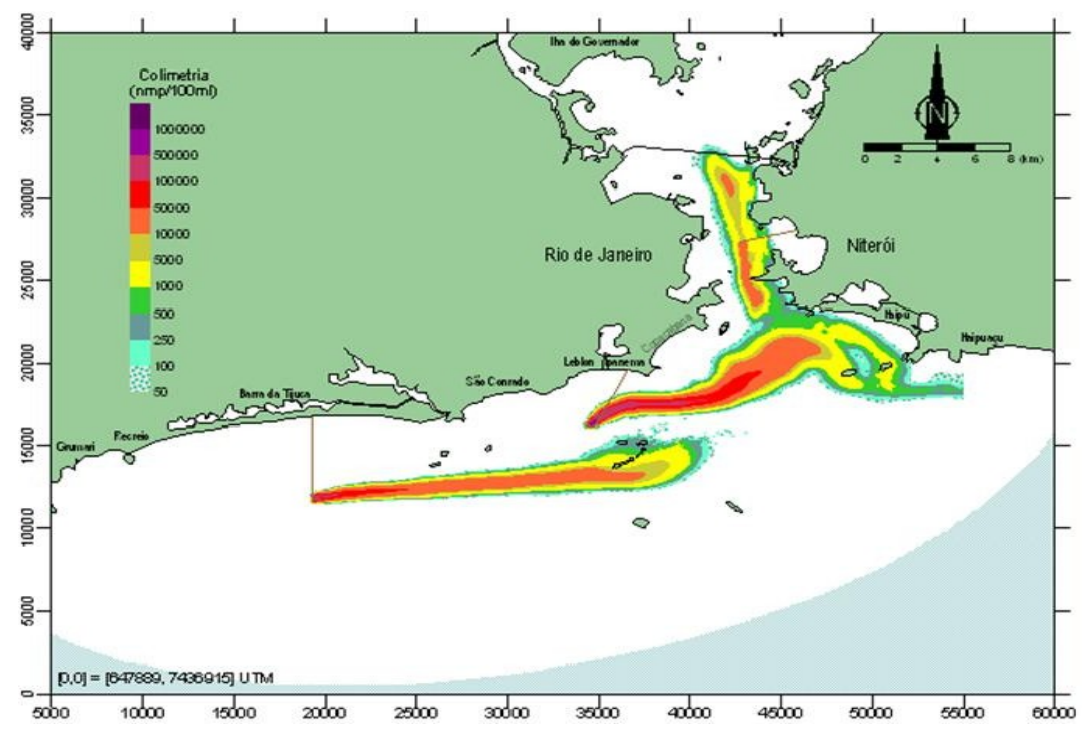

Figure 4: Fecal coliform concentrations in coastal waters under clear-sky summer conditions [11].

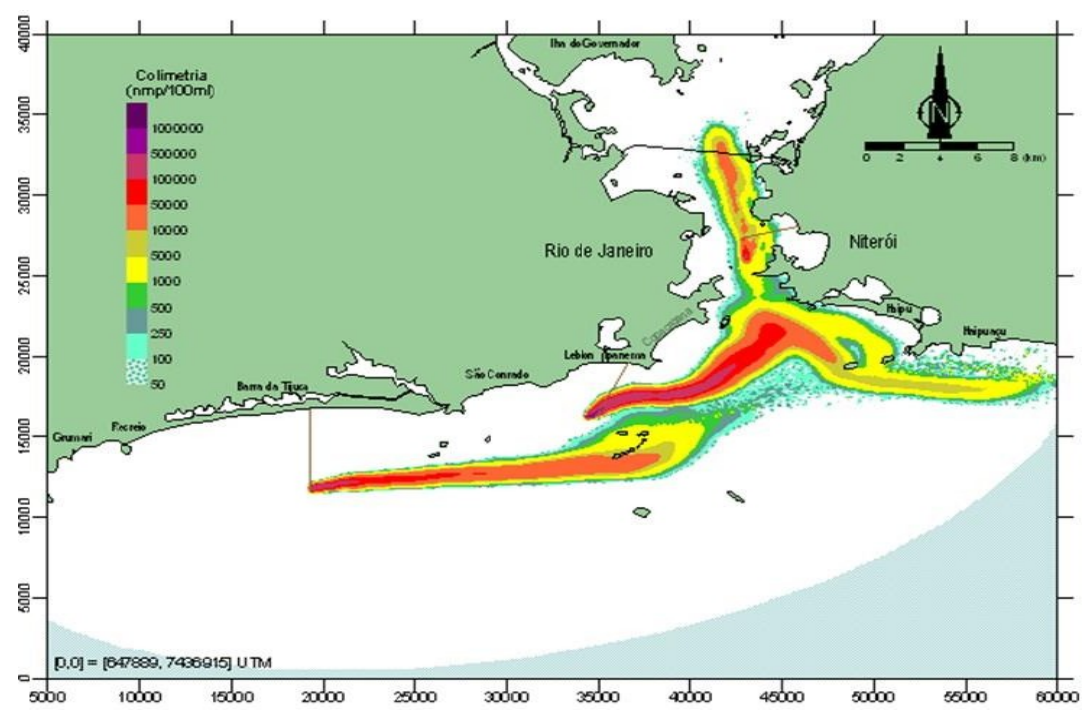

Figure 5: Fecal coliform concentrations in coastal waters under fully cloudy-sky summer conditions [11]. 


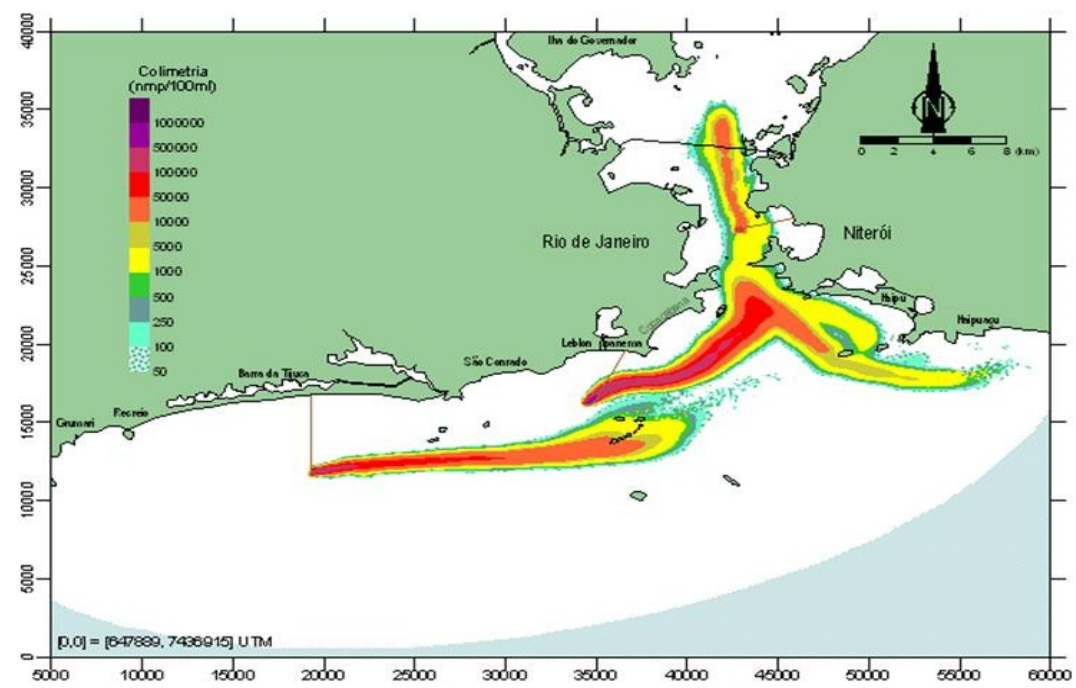

Figure 6: Fecal coliform concentrations in coastal waters under clear-sky winter conditions [11].

Given that Guanabara Bay has a long history of poor environmental care [5], effluent discharge from the submarine emissary is not the only source of pollution from Guanabara Bay [11], because according to Mesquita [14], Guanabara Bay receives the discharge of 50 rivers, of which 50 are considered completely polluted by sewage.

It is also essential to consider that the beaches located within Guanabara Bay already had their bathing conditions compromised due to the difficulty of the place to renew its water due to its brief section of water exchange with the ocean [5], [15].

The results show that the emissaries under study do not significantly imply in the water quality of the beaches, being indicated that such contamination occurs due to their connection with systems of rivers and channels that discharge their polluted waters in the coast and Guanabara Bay [11].

\section{BATHING CONDITIONS OF STUDY REGION BEACHES}

Bathing conditions data for the period from 2007 to 2019, provided by the Hydrometeorological and Water Quality Information Management (GeIHQ) - INEA-RJ, were analyzed between 2007 and 2013, samples were collected at only one monitoring point per beach and once a week.

Since 2014, the number of beach monitoring points increased, considering the length of each beach, and the collection periodicity was twice a week.

The monitoring points arranged along the beaches can be seen in Fig. 7 and Table 2. The samples are collected at an average depth of $1 \mathrm{~m}$, as it is the zone area of the bathers, and conducted for analysis in the own laboratory of the State Environmental Institute of Rio de Janeiro (INEA), where the faecal and temperature indicator levels of each sample are checked.

From the results of these analyses, the beaches are classified according to the standards established in CONAMA Resolution No. 274/2000 [13], thus generating the weekly bathing bulletins published by INEA, classifying the beaches as PROPER or IMPROPER for swimming [16]. 


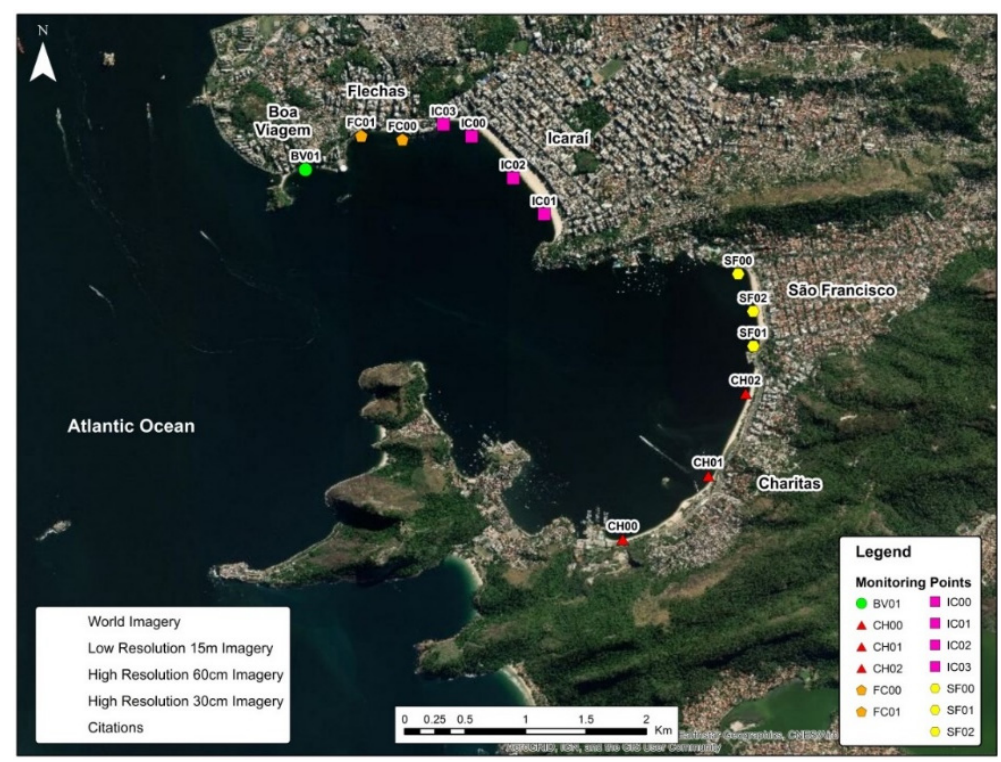

Figure 7: Location of sampling points in the Niteroi region. (Source: Adapted from INEA [16].)

Table 2: Monitoring points.

\begin{tabular}{ll}
\hline Beaches & Monitoring points \\
\hline Boa Viagem & BV 01 \\
Flechas & FC 00; FC 01 \\
Icarai & IC 00; IC 01; IC 02; IC 03 \\
São Francisco & SF 00; SF 01; SF 02 \\
Charitas & CH 00; CH 01; CH 02 \\
\hline
\end{tabular}

5 RESULTS AND DISCUSSION

\subsection{Bathing conditions}

A statistical analysis based on the data obtained was performed, and the evolution of the percentage of IMPROPER assessments of the beaches within the study area was traced between 2007 and 2013, as can be observed in Table 3, and between 2014 and 2019 according to Table 4.

From 2007 to 2010, excluding the beaches of São Francisco and Charitas that remained IMPROPER throughout the study period, the beaches of the study region maintained their beaches predominantly classified as PROPER by reaching a maximum IMPROPER percentage of $46 \%$, observed at Boa Viagem beach in 2008 .

However, in 2011 there was a rapid growth of IMPROPER conditions on the beaches of the study region, where the minimum of IMPROPER ratings was $77 \%$ on Boa Viagem beach. These terrible conditions remained until 2013, where $100 \%$ of the analyses performed on the samples of the beach of San Francisco indicated that it was IMPROPER for a primary contact. 
Table 3: Evolution of the bathing conditions between 2007 and 2013.

\begin{tabular}{|l|c|c|c|c|c|c|c|}
\hline \multicolumn{7}{|c|}{ Improper rating percentage } \\
\hline Beaches & 2007 & 2008 & 2009 & 2010 & 2011 & 2012 & 2013 \\
\hline Boa Viagem & $17 \%$ & $46 \%$ & $23 \%$ & $26 \%$ & $98 \%$ & $62 \%$ & $69 \%$ \\
\hline Flechas & $31 \%$ & $38 \%$ & $38 \%$ & $32 \%$ & $77 \%$ & $69 \%$ & $85 \%$ \\
\hline Icarai & $23 \%$ & $29 \%$ & $38 \%$ & $40 \%$ & $88 \%$ & $85 \%$ & $94 \%$ \\
\hline São Francisco & $56 \%$ & $96 \%$ & $94 \%$ & $82 \%$ & $100 \%$ & $100 \%$ & $100 \%$ \\
\hline Charitas & $54 \%$ & $88 \%$ & $100 \%$ & $90 \%$ & $100 \%$ & $100 \%$ & $90 \%$ \\
\hline
\end{tabular}

Table 4: Evolution of the bathing conditions between 2014 and 2019.

\begin{tabular}{|l|c|c|c|c|c|c|c|}
\hline \multicolumn{7}{|c|}{ Improper rating percentage } \\
\hline Beaches & Point & 2014 & 2015 & 2016 & 2017 & 2018 & 2019 \\
\hline Boa Viagem & BV 01 & $59 \%$ & $75 \%$ & $38 \%$ & $34 \%$ & $29 \%$ & $59 \%$ \\
\hline \multirow{3}{*}{ Flechas } & FC 00 & $41 \%$ & $36 \%$ & $44 \%$ & $23 \%$ & $34 \%$ & $56 \%$ \\
\cline { 2 - 8 } & FC 01 & $55 \%$ & $52 \%$ & $44 \%$ & $30 \%$ & $39 \%$ & $63 \%$ \\
\hline \multirow{5}{*}{ Icarai } & IC 00 & $46 \%$ & $41 \%$ & $57 \%$ & $35 \%$ & $44 \%$ & $78 \%$ \\
\cline { 2 - 8 } & IC 01 & $68 \%$ & $61 \%$ & $63 \%$ & $46 \%$ & $61 \%$ & $70 \%$ \\
\cline { 2 - 8 } & IC 02 & $15 \%$ & $25 \%$ & $36 \%$ & $23 \%$ & $32 \%$ & $52 \%$ \\
\cline { 2 - 8 } & IC 03 & $63 \%$ & $51 \%$ & $74 \%$ & $53 \%$ & $54 \%$ & $96 \%$ \\
\hline \multirow{5}{*}{ São Francisco } & SF 00 & $98 \%$ & $95 \%$ & $94 \%$ & $84 \%$ & $96 \%$ & $89 \%$ \\
\cline { 2 - 8 } & SF 01 & $88 \%$ & $83 \%$ & $89 \%$ & $60 \%$ & $73 \%$ & $89 \%$ \\
\cline { 2 - 8 } & SF 02 & $80 \%$ & $85 \%$ & $81 \%$ & $52 \%$ & $62 \%$ & $78 \%$ \\
\hline & CH 00 & $65 \%$ & $55 \%$ & $61 \%$ & $42 \%$ & $49 \%$ & $81 \%$ \\
\cline { 2 - 8 } & CH 01 & $40 \%$ & $48 \%$ & $58 \%$ & $25 \%$ & $52 \%$ & $48 \%$ \\
\cline { 2 - 7 } & CH 02 & $68 \%$ & $69 \%$ & $68 \%$ & $50 \%$ & $40 \%$ & $78 \%$ \\
\hline
\end{tabular}

From 2014 to 2018, excluding São Francisco beach, there was a gradual decrease of IMPROPER evaluations on the beaches of the study region. In 2019, the bathing conditions classified as IMPROPER returned to a significant increase and reached higher percentages. This is mainly because samples were analyzed only between January and April, which corresponds to the period with the highest rainfall of the year in the region under study.

\subsection{Pluviometric index versus bathing conditions}

Through the analysis of the obtained data was performed a correlation of the rainfall index of the city of Niteroi with the bathing conditions of its beaches. To establish such correlation (Fig. 8), it was used the average rainfall of the city of Niteroi [17] and the monthly average of "IMPROPER" assessments of Icarai beach, between 2014 and 2018.

Thus, the influence of rainfall on beach bathing conditions can be verified, since predominantly the beaching conditions of Icarai beach worsened as the average rainfall increased and, in the same way, the bathing conditions improved as the average rainfall decreased over the months of the year. 
This is due to the increased volume of water that is added to the sewage system and, consequently, capitated by the sewage treatment plants, which are unable to properly this effluent stream, thus occurring their overflow to nature [18].

Fig. 9 shows the correlation between Enterococcus levels found in samples collected from Icarai beach (IC 01), on days when precipitation occurred within 48 hours before sampling. It should be noted that precipitation data were obtained from the National Institute of Meteorology (INMET) website.

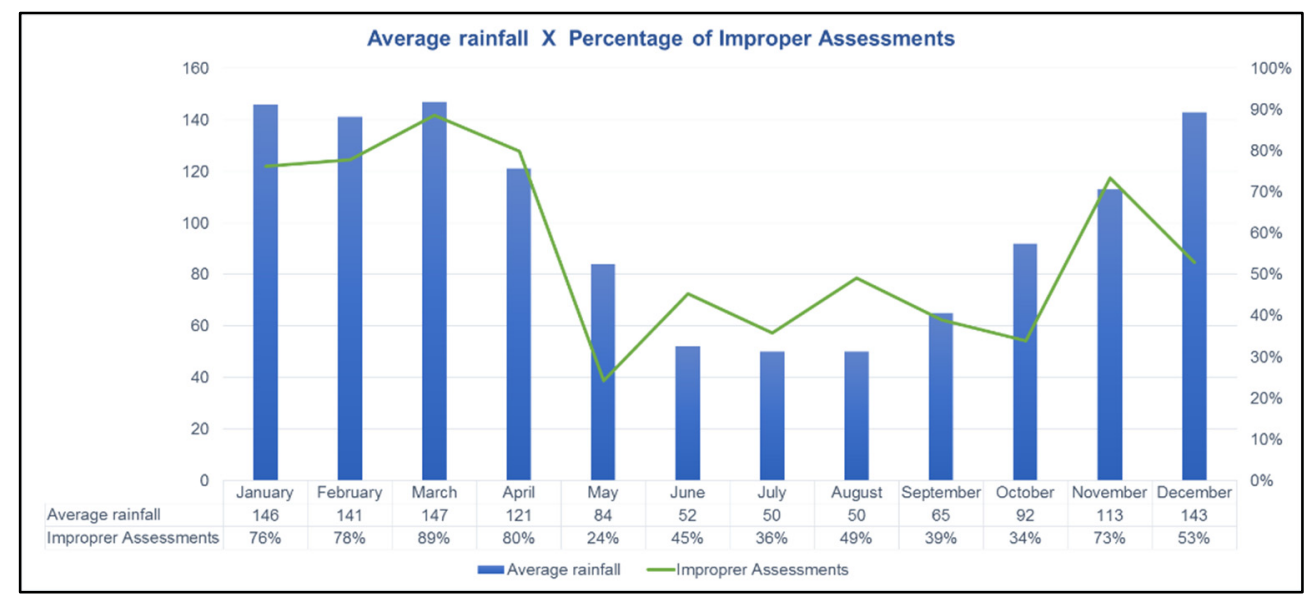

Figure 8: Correlation of Niteroi average rainfall with the percentage of IMPROPER assessments at sampling point IC 01 .

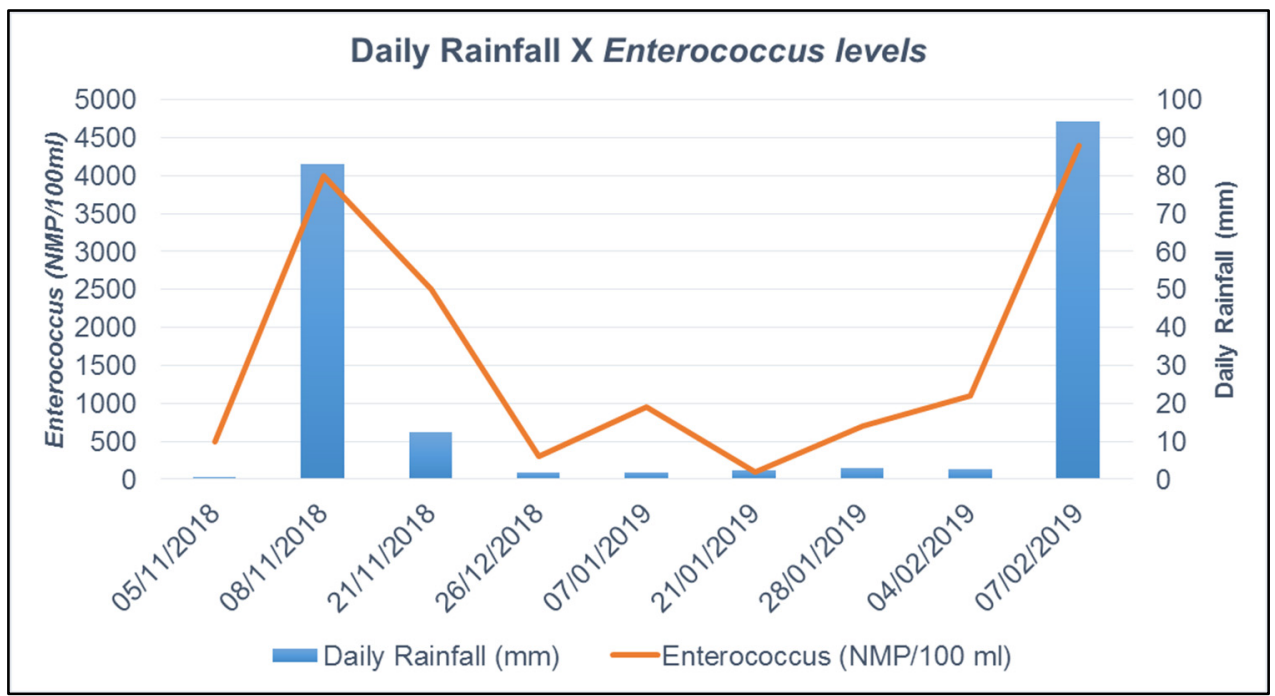

Figure 9: Correlation of daily rainfall with Enterococcus Levels in samples analyzed within 48 hours after precipitation at sampling point IC 01 between November 2018 and February 2019. 


\section{RESULTS AND DISCUSSION}

From the studies that make up this academic research, it was verified the existence of factors capable of influencing the conditions of bathing, that during the last 12 years did not show significant improvement despite the constant improvement and expansion of the sanitation system of Niteroi, as well as the implementation of the Icarai submarine outfall.

It is essential to highlight that the high pollution index found in Guanabara Bay may be the main factor influencing the bathing conditions of Niteroi beaches, which through the flow of currents and tides, leads pollution to the edge of the city of Niteroi. It is also noteworthy that the clandestine connections between rainwater and sewage networks play a very harmful role, especially in precipitation conditions, given that the increased flow leads to the overflow of effluents in the sewage catchment networks and, consequently, the flow of this into nature without any kind of treatment.

Thus, it was verified the existence of measures capable of reversing the current situation of Guanabara Bay and, consequently, improving the water quality of Niteroi beaches. It turns out that most, if not all, sanitation plans have been neglected and paralyzed by successive governments, which is why bathing conditions have been worsening considerably year after year.

Therefore, the conclusion of the Guanabara Bay Depollution Program is considered as a perspective capable of improving the bathing conditions of the beaches of Niteroi, so that there is an evolution of the local ecosystem as a whole, thus avoiding the distribution of pollution between Niteroi and the other cities bathed by Guanabara Bay.

Equally necessary is the massive investment in environmental education both in schools and in communities surrounding Guanabara Bay, as well as the implementation of more intense public policies and social programs to raise awareness of the impacts caused by inadequate waste disposal (garbage and Sewer).

\section{REFERENCES}

[1] National Sanitation Information System (SNIS). http://app4.cidades.gov.br/ serieHistorica/. Accessed on: 4 Jun. 2019.

[2] Silva, D.L., Avaliação do Plano Municipal de Saneamento Básico de Maricá com Vistas à sua Revisão. Trabalho de Conclusão de Curso Em Engenharia Ambiental, UFRJ, 2019.

[3] Brazilian Association of Engineering and Environmental Sanitation (ABES). http://aesbe.org.br/abes-divulga-ranking-da-universalizacao-do-saneamento/. Accessed on: 5 Jun. 2019.

[4] Scapucin, C., Talarico, M.F. \& Moura, R., Boletim de Inovação e Sustentabilidade Poluição dos Mares, São Paulo, 2018.

[5] Motta, L.A.T. \& Faria, P.I.D., Avaliação do Impacto do Lançamento de Poluentes por Emissários Submarinos e Fontes Costeiras Pontuais na Balneabilidade das Praias do Rio de Janeiro e Niterói. Trabalho de Conclusão de Curso Em Engenharia Ambiental, UFRJ, 2013.

[6] Carvalho, P.C.T., Despoluição de Recursos Hídricos: O caso da Baia da Guanabara. Trabalho de Conclusão de Curso Em Engenharia Civil, Universidade Federal de Juiz de Fora, 2013.

[7] Pinheiro, P., Doenças transmitidas por água contaminada. www.mdsaude.com/ doencas-infecciosas/doencas-da-agua/. Accessed on: 10 May 2019. 
[8] Costa, R.V.F., Desenvolvimento do Índice de Salubridade Ambiental (ISA) para Comunidades Rurais e sua Aplicação e Análise nas Comunidades de Ouro Branco MG. Tese de Mestrado Em Engenharia Ambiental, Universidade Federal de Ouro Preto, 2010.

[9] Treat Brazil Institute. www.tratabrasil.org.br/tratamento-dos-esgotos-em-niteroiavancam-e-municipio-esta-perto-da-universalizacao. Accessed on: 15 Jun. 2019.

[10] Feitosa, R.C. \& Rosman, P.C.C., Emissários submarinos de esgoto: aspectos de qualidade de água e modelagem computacional. Métodos Numéricos em Recursos Hídricos (Vol. 8), Capítulo 1. Associação Brasileira de Recursos Hídricos - ABRH.

[11] Feitosa, R.C., Emissários submarinos de esgotos como alternativa à minimização de riscos à saúde humana e ambiental. Ciênc Saúde Coletiva, 22, pp. 2037-2048,2017.

[12] Ratti, B.A. et al. Pesquisa de coliformes totais e fecais em amostras de água coletadas no bairro zona sete, na cidade de maringá-pr. 4.

[13] CONAMA, Resolução 274/2000. Conselho Nacional de Meio Ambiente, 2000. www.mma.gov.br/port/conama. Accessed on: 17 Jun. 2019.

[14] Mesquita, J.L., Baía de Guanabara, apesar de quase morta, não provoca indignação. https://marsemfim.com.br/baia-de-guanabara-entenda-poluicao/. Accessed on: 5 Jun. 2019.

[15] Nasser, V.L., Estudo da Qualidade de Água na Baía de Guanabara Utilizando Técnicas de Sensoriamento Remoto e Análise Geoestatística. Tese de Mestrado Em Engenharia Civil, COPPE/UFRJ, 2001.

[16] Instituto Estadual do Ambiente (INEA). www.inea.rj.gov.br/Portal/MegaDropDown/ Monitoramento/Qualidadedaagua/Praias/index.htm. Accessed on: 10 Jan. 2019.

[17] CLIMATE-DATA, 2019. https://pt.climate-data.org/america-do-sul/brasil/rio-dejaneiro/niteroi-1772/\#climate-graph.

[18] O GLOBO, Entenda como funciona o despejo de esgoto por emissários submarinos, http://redeglobo.globo.com/globoecologia/noticia/2013/10/entenda-como-funcionao-despejo-de-esgoto-por-emissarios-submarinos.html. Accessed 5 Jun. 2019. 